\title{
Effect of equine chorionic gonadotropin treatment during a progesterone- based timed artificial insemination program on reproductive performance in seasonal-calving lactating dairy cows
}

\author{
Federico Randi, ${ }^{*} †$ José Maria Sánchez, ${ }^{*}$ Mary M. Herlihy,‡ Alessio Valenza,§ David A. Kenny,† \\ Stephen T. Butler, $\ddagger$ and Patrick Lonergan*1 \\ *School of Agriculture and Food Science, University College Dublin, Belfield, Dublin, Ireland D04N2E5 \\ †AGRIC Teagasc Grange, Dunsany, Meath, Ireland C15PW93 \\ ¥AGRIC Teagasc Moorepark, Fermoy, Cork, Ireland P61C996 \\ $\S C E V A$ Santé Animale, Libourne 33500, France
}

\begin{abstract}
The aim of this study was to investigate the effect of progesterone (P4)-based timed artificial insemination (TAI) programs on fertility in seasonal-calving, pasture-based dairy herds. A total of 1,421 lactating dairy cows on 4 spring-calving farms were stratified based on days in milk (DIM) and parity and randomly allocated to 1 of 3 treatments: (1) control: no hormonal treatment; cows inseminated at detected estrus; (2) P4Ovsynch: cows received a 7-d P4-releasing intravaginal device (PRID Delta; CEVA Santé Animale, Libourne, France) with $100 \mu \mathrm{g}$ of a gonadotropin-releasing hormone (GnRH) analog (Ovarelin; CEVA Santé Animale) at PRID insertion, a 25-mg injection of $\mathrm{PGF}_{2 \alpha}$ (Enzaprost; CEVA Santé Animale) at PRID removal, $\mathrm{GnRH}$ at $56 \mathrm{~h}$ after device removal and TAI $16 \mathrm{~h}$ later;

(3) P4-Ovsynch+eCG: the same as P4-Ovsynch, but cows received $500 \mathrm{IU}$ of equine chorionic gonadotropin (eCG; Syncrostim; CEVA Santé Animale) at PRID removal. At $10 \mathrm{~d}$ before mating start date (MSD), all cows that were $\geq 35$ DIM were examined by transrectal ultrasound to assess presence or absence of a corpus luteum; body condition score (BCS) was also recorded. Pregnancy diagnosis was performed by transrectal ultrasonography 30 to $35 \mathrm{~d}$ after insemination. Overall pregnancy/AI (P/AI) was not different between groups (50.9, 49.8, and $46.3 \%$ for control, P4-Ovsynch, and $\mathrm{P} 4-\mathrm{Ovsynch}+\mathrm{eCG}$, respectively) but the 21-d pregnancy rate was increased by the use of synchronization (35.0, 51.7, and 47.2\%, respectively). Compared with the control group, synchronization significantly reduced the interval from MSD to conception (34.6, 23.0, and $26.5 \mathrm{~d}$, respectively) and consequently reduced the
\end{abstract}

Received January 25, 2018.

Accepted June 28, 2018.

${ }^{1}$ Corresponding author: pat.lonergan@ucd.ie average days open $(98.0,86.0$, and 89.0 d). Across all treatment groups, DIM at the start of synchronization affected P/AI (42.3, 49.5, and $53.9 \%$ for $<60,60-80$, and $>80$ DIM, respectively), but neither parity (46.5, 50.4 , and $48.4 \%$ for parity 1,2 , and $\geq 3$, respectively) nor BCS $(44.0,49.4$, and $58.6 \%$ for $\leq 2.50,2.75-3.25$, and $\geq 3.50$, respectively) affected the likelihood of $\mathrm{P} /$ AI. Two-way interactions between treatment and DIM, parity, or BCS were not detected. In conclusion, the use of TAI accelerated pregnancy establishment in cows in a pasture-based system by reducing days open, but eCG administration at PRID removal did not affect P/ AI.

Key words: timed artificial insemination, pasturebased dairy production, equine chorionic gonadotropin, submission rate, pregnancy/AI

\section{INTRODUCTION}

The economic advantage of pasture-based seasonal dairy production systems depends on the ability to match pasture growth with herd dietary requirements to maximize the amount of milk from grazed grass (Dillon et al., 1995). Good fertility and compact calving are essential to maximize pasture utilization and hence farm profit. The target is for $90 \%$ of the herd to have calved within $42 \mathrm{~d}$ from the planned start of calving and all cows calved by mating start date (MSD). For a 100-cow herd, increasing the 6 -wk calving rate from 70 to $90 \%$ is worth $€ 16,500 / y r$ (Shalloo et al., 2014). To maintain the annual calving pattern, cows need to conceive during a relatively short window postpartum, during a period when cows are frequently under metabolic stress.

The most important metrics in such a system are 21-d submission rate (21-d SR); that is, the proportion of eligible cows presented for insemination within the first $3 \mathrm{wk}$ of the breeding season, and the 21-d and 
42-d pregnancy rates (21-d PR and 42-d PR); that is, the proportion of cows pregnant by 3 and 6 wk of the breeding season, respectively. The target 21-d SR in seasonal-calving systems is $90 \%$, which requires that most cows should have resumed normal ovarian cyclicity before MSD. Failure to meet this target is primarily caused by failure to detect cows in estrus, largely based on the evaluation of tail paint removal at milking, but it can be exacerbated when there is a high proportion of anovular cows in the herd (Rhodes et al., 2003). Both of these issues have been addressed in the past with the use of timed AI (TAI) programs, which avoids the requirement for estrus detection (Pursley et al., 1995). Furthermore, administration of equine chorionic gonadotropin (eCG) as part of the synchronization regimen has been shown to have a favorable effect on cows that did not show signs of estrus before MSD and cows diagnosed as anovular based on the absence of a corpus luteum (CL) during examination of the ovaries (Bryan et al., 2010, 2013; Shephard, 2013).

One of the main advantages of TAI programs is that a large proportion of cows have the opportunity to conceive at the start of the seasonal breeding period. One way to optimize time and labor is to use systematic programs to manage reproduction. In both confined (Caraviello et al., 2006; Bó et al., 2013) and seasonal-calving pasture-based systems (McDougall, 2010; Herlihy et al., 2011), the use of systematic estrous and ovulation synchronization protocols has been demonstrated to improve various metrics of herd reproductive efficiency.

The aim of this study was to investigate the effectiveness of progesterone (P4)-based ovulation synchronization protocols for TAI in dairy cows on a spring-calving pasture-based system, and to test the hypothesis that eCG treatment during the TAI protocol would improve pregnancy per AI.

\section{MATERIALS AND METHODS}

\section{Experimental Design}

This study was conducted using lactating HolsteinFriesian and Jersey $\times$ Holstein-Friesian crossbred dairy cows $(\mathrm{n}=1,421)$ on 4 commercial spring-calving herds across 2 seasons (April 2015 to July 2015 and April 2016 to July 2016). On each farm, cows were milked twice a day for the duration of the trial and managed as a single herd on fresh pasture and supplemented with variable quantities of concentrate at milking (0.5 to 4.0 $\mathrm{kg}$ concentrate per day depending on grass growth and pasture availability).

At $10 \mathrm{~d}$ before MSD, all cows that were $\geq 30$ DIM were examined by transrectal ultrasonography to as- sess the presence or absence of a CL and dominant follicle(s). Body condition score was recorded on a scale of 1 to 5 , where 1 corresponds to emaciated and 5 to obese (Edmonson et al., 1989). Cows exhibiting obvious uterine pathological conditions were excluded. Cows were then randomized according to parity number and DIM and allocated to 1 of 3 treatments (Figure 1): (1) control (no hormonal treatment): cows inseminated at detected estrus; (2) P4-Ovsynch: cows received a 7-d P4-releasing intravaginal device (PRID Delta, containing $1.55 \mathrm{~g}$ of progesterone; CEVA Santé Animale, Libourne, France) with $100 \mu \mathrm{g}$ of a GnRH analog (Ovarelin, $100 \mu \mathrm{g}$ of gonadorelin diacetate tetrahydrate; CEVA Santé Animale) at PRID insertion, an injection of $\mathrm{PGF}_{2 \alpha}$ (Enzaprost, $25 \mathrm{mg}$ of dinoprost trometamol; CEVA Santé Animale) at PRID removal, $\mathrm{GnRH}$ at 56 $\mathrm{h}$ after device removal, and TAI $16 \mathrm{~h}$ later; (3) P4Ovsynch+eCG: same as P4-Ovsynch but cows also received $500 \mathrm{IU}$ equine chorionic gonadotropin (eCG; Syncrostim, CEVA Santé Animale) at PRID removal.

A second round of TAI was conducted on 3 of the 4 farms for later-calving cows using the same treatments outlined above. The second round was initiated on $\mathrm{d} 11$ after the farm MSD, resulting in TAI for the synchronized cows on d 21 after the farm MSD. Pregnancy diagnosis was performed by transrectal ultrasonography 30 to $35 \mathrm{~d}$ after insemination.

\section{Statistical Analysis}

Data were analyzed using SAS software (version 9.3; SAS Institute Inc., Cary, NC). The effect of synchronization treatment on the binary traits was determined using generalized linear mixed models (GLIMMIX procedure). The binary traits were 21 -d SR (percentage of cows presented for insemination with 3 wk of MSD), pregnancy to first AI (P/AI, percentage of cows confirmed pregnant by ultrasonography $30 \mathrm{~d}$ after TAI), 21-d PR and 42-d PR (percentage of cows that successfully established pregnancy during the first 21 and $42 \mathrm{~d}$ of the breeding season, respectively), and end-of-season final pregnancy rate (FPR, percentage of cows pregnant at the end of the 12-wk breeding season). Explanatory independent variables considered for inclusion in all models were synchronization treatment $(\mathrm{n}=3)$, farm $(\mathrm{n}=4)$, parity of the cow $(1,2$, and $\geq 3)$, DIM at MSD $(<60,60$ to $80,>80)$, round $(\mathrm{n}=2)$, BCS $(\leq 2.50 .2 .75$ to $3.25, \geq 3.50)$, CL presence at treatment initiation $(0,1)$, dominant follicle presence at treatment initiation $(0,1)$, and all possible 2 -way interaction terms involving synchronization treatment. Treatment, farm, and parity were retained in all models, and all other explanatory variables and 2-way interactions 

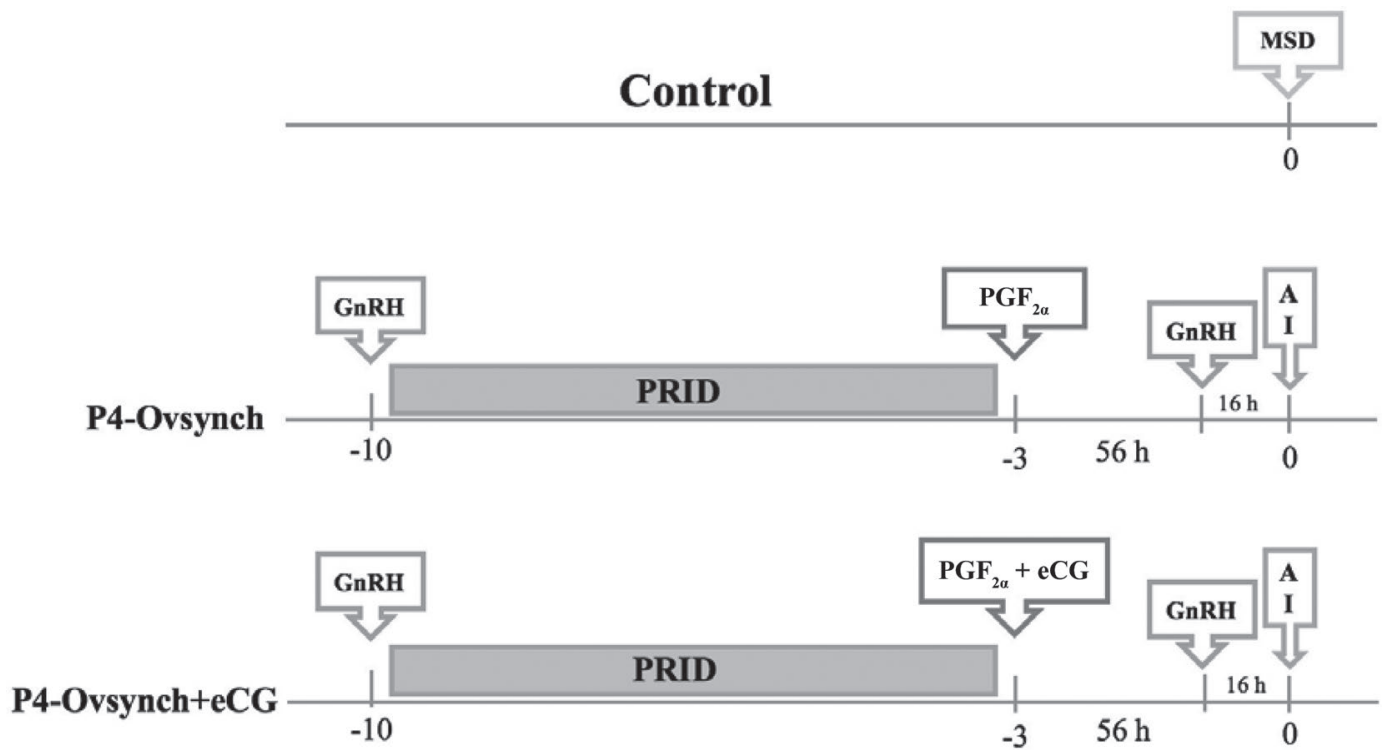

Figure 1. Schematic diagram of the synchronization protocols used in the study. Cows were randomly assigned to the following groups: (1) Control - no treatment, bred at detected estrus (mating start day, MSD); (2) P4-Ovsynch - a 7-d progesterone-releasing intravaginal device (PRID) with gonadotropin-releasing hormone $(\mathrm{GnRH})$ at PRID insertion and a luteolytic dose of PGF P $_{2 \alpha}$ at PRID removal; or (3) P4Ovsynch+eCG - a 7-d PRID with GnRH at PRID insertion and a luteolytic dose of PGF P $_{2 \alpha}$ plus 500 IU of equine chorionic gonadotropin (eCG) at PRID removal. Cows in treatments 2 and 3 received GnRH $56 \mathrm{~h}$ after PRID removal with timed AI performed $16 \mathrm{~h}$ later.

were retained in the final models if significant $(P<$ 0.1 ). Preplanned contrasts were used to compare ovulation synchronization treatments against each other (P4-Ovsynch vs. P4-Ovsynch+eCG) and to compare ovulation synchronization treatments combined (P4Ovsynch and P4-Ovsynch+eCG) versus the control treatment. The interval from MSD to conception was also evaluated by the LIFETEST procedure of SAS using Kaplan-Meier analysis to investigate the effect of treatment on days from start of breeding to conception. If a cow did not conceive during the breeding season, the cow was right-censored at the maximum permissible value of $84 \mathrm{~d}$ (i.e., $12 \mathrm{wk}$ of breeding allowed). The data are presented graphically as a survival distribution function by days after MSD (Figure 2).

\section{RESULTS}

A total of 53 cows presenting uterine pathologies at the time of ultrasound examination were excluded from the study. The fixed effect of farm was significant for all of the fertility variables investigated (21-d SR, P/ AI, 21-d PR, 42-d PR, and FPR; all $P<0.05)$. Pregnancy to first AI did not differ between treatments (50.9, 48.0, and $46.3 \%$ for control, P4-Ovsynch, and $\mathrm{P} 4-\mathrm{Ovsynch}+\mathrm{eCG}$, respectively; $P=0.9$ ). The $21-\mathrm{d}$ PR was increased following TAI (35.0, 51.7, and $47.2 \%$ for control, P4-Ovsynch, and P4-Ovsynch+eCG, re- spectively; $P<0.0001)$. The $42-\mathrm{d} \mathrm{PR}$ was affected by treatment, farm, and round $(P=0.02, P<0.0001$, $P<0.0001$, respectively). The FPR was affected by treatment, farm, and round $(P=0.005, P<0.0001, P$ $=0.002$, respectively; Table 1 ).

Compared with the control treatment, P4-Ovsynch and P4-Ovsynch+eCG treatments reduced the interval from MSD to conception (34.6, 23.0, and $26.5 \mathrm{~d}$, respectively; $P<0.001$, Figure 2), and consequently reduced the average days open $(98.0,86.0$, and $89.0 \mathrm{~d}$, respectively). Across all treatment groups, DIM at the start of the TAI protocol affected P/AI $(42.3,49.5$, and $53.9 \%$ for $<60,60-80$, and $>80$ DIM, respectively; $P<$ $0.03)$, but neither parity number $(46.5,50.4$, and $48.4 \%$ for parity 1,2 , and $\geq 3$, respectively; $P=0.6$ ) nor BCS $(44.0,49.4$, and $58.6 \%$ for $\leq 2.50,2.75-3.25$, and $\geq 3.50$, respectively; $P=0.18$ ) affected $\mathrm{P} / \mathrm{AI}$ (Table 2). No two-way interactions between treatment and all other explanatory variables were detected (all $P>0.05)$. The 21-d PR was affected by farm $(P<0.0001)$ and CL status at start of TAI protocol $(P=0.006$; Table 3$)$ whereas 42-d PR was affected by farm $(P<0.0001$; Table 4).

\section{DISCUSSION}

This study investigated the effect of applying a systematic, whole-herd P4-based TAI program on repro- 


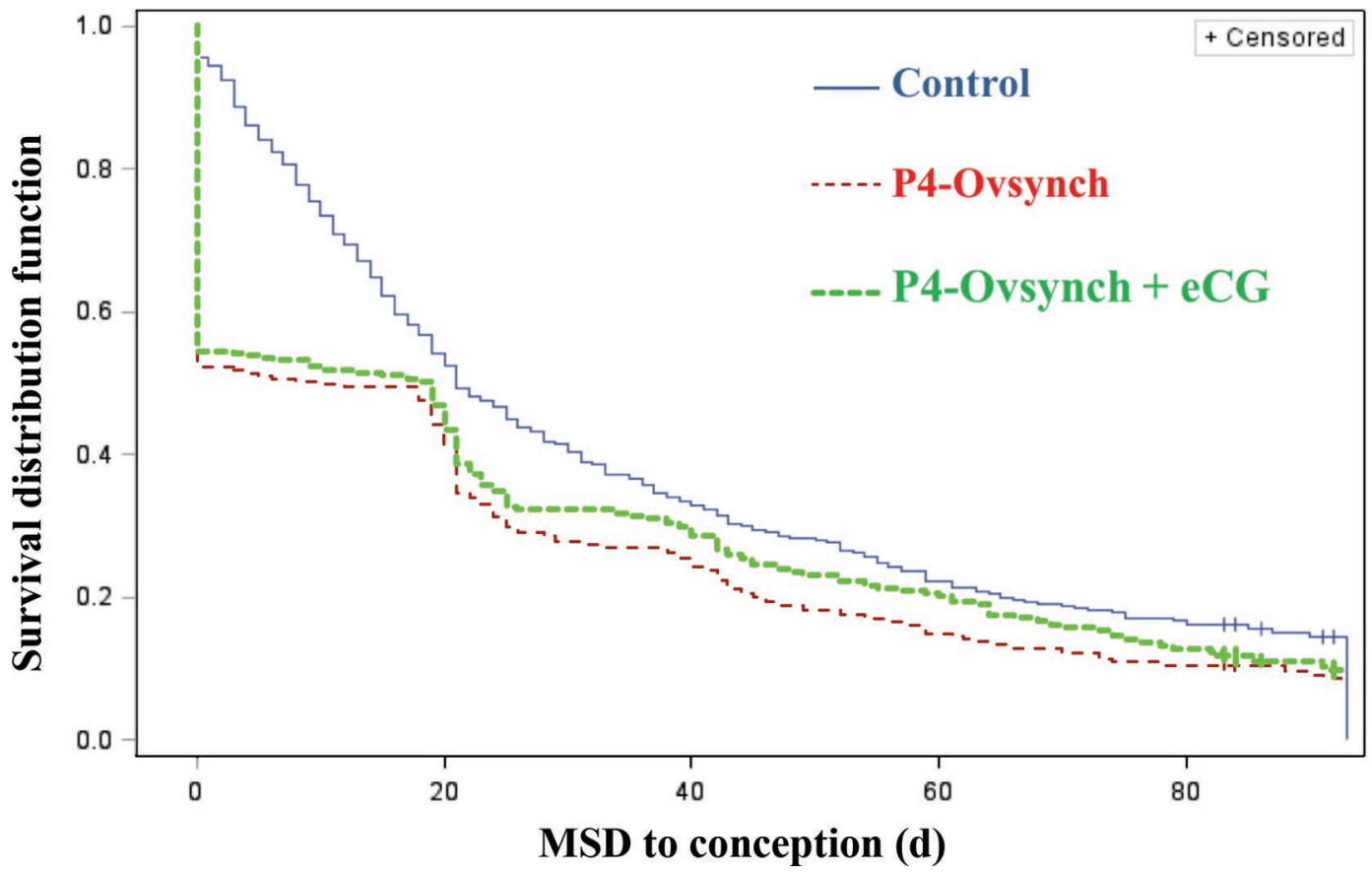

Figure 2. Survival distribution function for the interval in days from mating start day (MSD) to conception for control cows (solid/blue curve) detected in estrus by tail paint removal twice daily and inseminated on the basis of the a.m./p.m. rule, P4-Ovsynch timed AI (thin dashed/red curve), or P4-Ovsynch+eCG timed AI (thick dashed/green curve) and subsequently inseminated on the basis of estrus detected following the same procedure of the control group. Control = no treatment; P4-Ovsynch = a 7-d progesterone-releasing intravaginal device (PRID) with gonadotropin-releasing hormone $(\mathrm{GnRH})$ at PRID insertion and a luteolytic dose of $\mathrm{PGF}_{2 \alpha}$ at PRID removal; P4-Ovsynch+eCG $=$ a $7-\mathrm{d}$ PRID with GnRH at PRID insertion and a luteolytic dose of PGF $_{2 \alpha}$ plus 500 IU of equine chorionic gonadotropin (eCG) at PRID removal. Color version available online.

ductive performance of spring-calving, pasture-based lactating dairy cows and examined whether treatment with eCG at P4 device removal at the end of the TAI protocol would affect P/AI. Overall, use of TAI improved reproductive performance, increasing 21-d PR, 42-d PR, and FPR, and reducing the number of days open compared with control cows receiving no hormonal intervention.

The likelihood of pregnancy establishment in cows submitted to TAI following an Ovsynch program is

Table 1. Effect of timed AI (TAI) on 21-d submission rate (SR), pregnancy to first AI (P/AI), and 21-d, 42-d, and final pregnancy rates (PR)

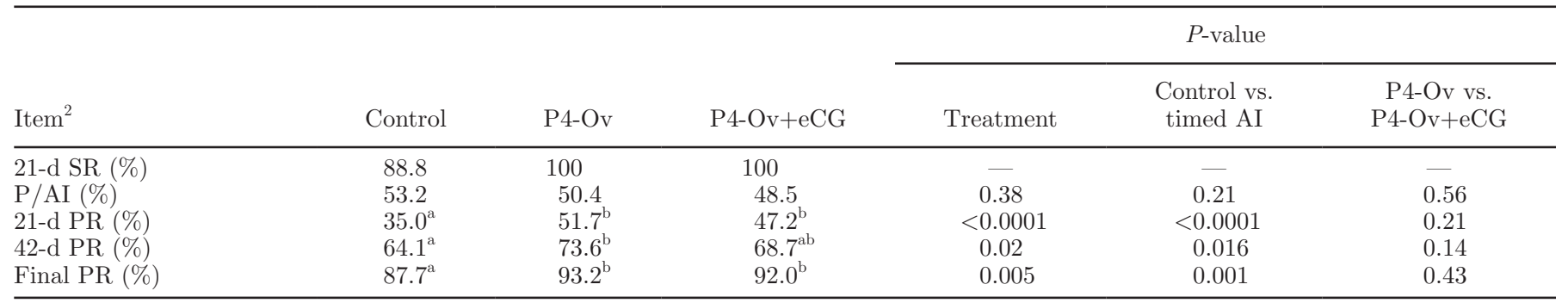

${ }^{\mathrm{a}, \mathrm{b}}$ Values within the same row with different superscripts differ significantly $(P<0.05)$.

${ }^{1}$ Control $=$ no treatment, bred at detected estrus (MSD); P4-Ov = a 7-d progesterone-releasing intravaginal device (PRID) with gonadotropinreleasing hormone $(\mathrm{GnRH})$ at PRID insertion and a luteolytic dose of $\mathrm{PGF}_{2 \alpha}$ at PRID removal; P4-Ov+eCG = a 7-d PRID with GnRH at PRID insertion and a luteolytic dose of $\mathrm{PGF}_{2 \alpha}$ plus $500 \mathrm{IU}$ of equine chorionic gonadotropin (eCG) at PRID removal. Cows in treatments 2 and 3 received GnRH $56 \mathrm{~h}$ after PRID removal with TAI performed $16 \mathrm{~h}$ later.

${ }^{2} 21$-d SR = percentage of eligible cows presented for insemination within the first weeks of the breeding season; $\mathrm{P} / \mathrm{AI}=$ percentage of cows confirmed pregnant by ultrasonography $30 \mathrm{~d}$ after TAI; 21-d and 42-d PR = percentage of cows that successfully established pregnancy during the first 21 and $42 \mathrm{~d}$ of the breeding season, respectively; final pregnancy rate = percentage of cows pregnant at the end of the 12 -wk breeding season. 
influenced by the day of the estrous cycle when the protocol is initiated (Keith et al., 2005). Based on this knowledge, several "presynchronization" protocols have been designed to ensure the initiation of Ovsynch at the most appropriate time, ideally between d 5 and 9 of the estrous cycle (reviewed in Wiltbank and Pursley, 2014). Prolonged TAI protocols that include presynchronization are impractical in seasonal-calving systems, where it is imperative that pregnancy establishment occurs as rapidly as possible after the start of the breeding period to maximize farm profitability (Shalloo et al., 2014).

Supplementation with P4 between the first GnRH injection and the $\mathrm{PGF}_{2 \alpha}$ injection in TAI programs has proven to be efficacious in improving pregnancy per AI in dairy cows. In a large-scale meta-analysis (Bisinotto et al., 2015), the beneficial effect of supplemental P4 was primarily seen in cows that did not have a CL at protocol initiation, whereas cows that did have a detectable CL were not affected by P4 supplementation.

In 2 recent studies involving experimental conditions similar to those used in the current study, the $\mathrm{P} / \mathrm{AI}$ reported for Ovsynch was lower $(45 \%)$ than that for AI after spontaneous estrus (53\%), whereas inclusion of a P4-releasing device in the Ovsynch protocol resulted in a P/AI similar to a spontaneous estrus (54\%; Herlihy et al., 2011). Further analysis of that data set (Herlihy et al., 2013) indicated that inclusion of a P4releasing device was most advantageous in cows early in the postpartum period ( $<80 \mathrm{~d}$ post-calving) and also in cows that were anestrous at the time of protocol initiation. In anestrous cows, the first GnRH injection is capable of inducing ovulation in a large proportion of the treated animals, but the lifespan of the induced CL is short in some cows (reviewed in Bó et al., 2013).

Table 2. Effect of farm, parity, presence of a corpus luteum (CL), BCS, and DIM at mating start date (MSD) on pregnancy to first $\mathrm{AI}(\mathrm{P} / \mathrm{AI})$ following timed $\mathrm{AI}^{1,2}$

\begin{tabular}{|c|c|c|c|c|c|}
\hline \multirow[b]{2}{*}{ Variable } & \multirow[b]{2}{*}{ Category } & \multicolumn{3}{|c|}{ P/AI, \% (no./total) } & \multirow[b]{2}{*}{$P$-value } \\
\hline & & Control & $\mathrm{P} 4-\mathrm{Ov}$ & $\mathrm{P} 4-\mathrm{Ov}+\mathrm{eCG}$ & \\
\hline \multirow[t]{7}{*}{ Farm } & 1 & $\begin{array}{l}60.8 \\
(73 / 120)\end{array}$ & $\begin{array}{l}60.3 \\
(76 / 126)\end{array}$ & $\begin{array}{l}63.8 \\
(74 / 116)\end{array}$ & 0.05 \\
\hline & 2 & 56.6 & 48.2 & 53.7 & \\
\hline & & $(30 / 53)$ & $(26 / 54)$ & $(29 / 54)$ & \\
\hline & 3 & 44.3 & 47.6 & 40.2 & \\
\hline & & $(35 / 79)$ & $(20 / 105)$ & $(45 / 112)$ & \\
\hline & 4 & 57.0 & 49.7 & 45.6 & \\
\hline & & (110/193) & $(97 / 195)$ & $(88 / 193)$ & \\
\hline \multirow[t]{5}{*}{ Parity } & 1 & $\begin{array}{l}52.7 \\
(59 / 112)\end{array}$ & $\begin{array}{l}50.4 \\
(62 / 123)\end{array}$ & $\begin{array}{l}52.9 \\
(63 / 119)\end{array}$ & 0.6 \\
\hline & 2 & 57.5 & 54.3 & 49.6 & \\
\hline & & $(65 / 113)$ & $(63 / 116)$ & (58/117) & \\
\hline & $\geq 3$ & 56.4 & 51.5 & 48.1 & \\
\hline & & $(124 / 220)$ & $(124 / 241)$ & $(115 / 239)$ & \\
\hline \multirow[t]{3}{*}{ CL status } & Absent & $\begin{array}{l}52.2 \\
(72 / 138)\end{array}$ & $\begin{array}{l}47.4 \\
(74 / 156)\end{array}$ & $\begin{array}{l}45.9 \\
(67 / 146)\end{array}$ & 0.9 \\
\hline & Present & 57.0 & 53.8 & 51.2 & \\
\hline & & $(172 / 302)$ & $(172 / 320)$ & $(167 / 326)$ & \\
\hline \multirow[t]{5}{*}{ BCS } & $\leq 2.5$ & 57.4 & 49.2 & 40.9 & 0.18 \\
\hline & & $(35 / 61)$ & $(31 / 63)$ & $(29 / 71)$ & \\
\hline & $2.75-3.25$ & 55.5 & 52.1 & 50.4 & \\
\hline & & $(202 / 364)$ & $(211 / 405)$ & $(190 / 377)$ & \\
\hline & $\geq 3.5$ & 55.0 & 58.3 & 63.0 & \\
\hline \multirow[t]{5}{*}{ DIM at MSD } & $<60 \mathrm{~d}$ & $\begin{array}{l}(11 / 20) \\
49.4\end{array}$ & 46.0 & $\begin{array}{l}(17 / 27) \\
44.6\end{array}$ & 0.03 \\
\hline & & $(82 / 166)$ & $(88 / 191)$ & $(86 / 193)$ & \\
\hline & $60-80 \mathrm{~d}$ & 59.3 & 52.9 & 51.4 & \\
\hline & & $(124 / 209)$ & $(117 / 221)$ & $(110 / 214)$ & \\
\hline & $>80 \mathrm{~d}$ & 60.0 & 64.7 & 58.8 & \\
\hline
\end{tabular}

${ }^{1}$ Data are presented as raw means, and $P$-values are model adjusted.

${ }^{2} \mathrm{Control}=$ no treatment, bred at detected estrus (MSD); $\mathrm{P} 4-\mathrm{Ov}=\mathrm{a}$ 7-d progesterone-releasing intravaginal device (PRID) with gonadotropin-releasing hormone $(\mathrm{GnRH})$ at PRID insertion and a luteolytic dose of $\mathrm{PGF}_{2 \alpha}$ at PRID removal; P4-Ov+eCG $=$ a 7-d PRID with GnRH at PRID insertion and a luteolytic dose of PGF ${ }_{2 \alpha}$ plus 500 IU of equine chorionic gonadotropin (eCG) at PRID removal. Cows in treatments 2 and 3 received GnRH $56 \mathrm{~h}$ after PRID removal with timed AI performed $16 \mathrm{~h}$ later. 
Table 3. Effect of farm, parity, presence of a corpus luteum (CL), BCS, and DIM at mating start date (MSD) on 21-d pregnancy rate (percentage of cows that successfully established pregnancy during the first $21 \mathrm{~d}$ of the breeding season $)^{1,2}$

\begin{tabular}{|c|c|c|c|c|c|}
\hline \multirow[b]{2}{*}{ Variable } & \multirow[b]{2}{*}{ Category } & \multicolumn{3}{|c|}{21 -d pregnancy rate, $\%$ (no./total) } & \multirow[b]{2}{*}{$P$-value } \\
\hline & & Control & $\mathrm{P} 4-\mathrm{Ov}$ & $\mathrm{P} 4-\mathrm{Ov}+\mathrm{eCG}$ & \\
\hline \multirow[t]{7}{*}{ Farm } & 1 & $\begin{array}{l}54.2 \\
(65 / 120)\end{array}$ & $\begin{array}{l}71.4 \\
(90 / 126)\end{array}$ & $\begin{array}{l}71.6 \\
(83 / 116)\end{array}$ & $<0.0001$ \\
\hline & 2 & 36.4 & 59.3 & 61.1 & \\
\hline & & $(20 / 55)$ & $(32 / 54)$ & $(33 / 54)$ & \\
\hline & 3 & 27.6 & 51.4 & 43.8 & \\
\hline & & $(27 / 98)$ & $(54 / 105)$ & $(49 / 112)$ & \\
\hline & 4 & 64.3 & 71.3 & 65.3 & \\
\hline & & (124/193) & $(139 / 195)$ & $(126 / 193)$ & \\
\hline \multirow[t]{5}{*}{ Parity } & 1 & $\begin{array}{l}50.4 \\
(59 / 117)\end{array}$ & $\begin{array}{l}65.9 \\
(81 / 123)\end{array}$ & $\begin{array}{l}67.2 \\
(80 / 119)\end{array}$ & 0.6 \\
\hline & 2 & 59.1 & 66.4 & 65.0 & \\
\hline & & $(68 / 115)$ & $(77 / 116)$ & $(76 / 117)$ & \\
\hline & $\geq 3$ & 46.6 & 65.2 & 56.5 & \\
\hline & & $(109 / 234)$ & $(157 / 241)$ & $(135 / 239)$ & \\
\hline \multirow[t]{3}{*}{ CL status } & Absent & $\begin{array}{l}40.7 \\
(59 / 145)\end{array}$ & $\begin{array}{l}57.1 \\
(89 / 156)\end{array}$ & $\begin{array}{l}55.5 \\
(81 / 146)\end{array}$ & 0.006 \\
\hline & Present & 55.4 & 69.7 & 63.8 & \\
\hline & & $(175 / 316)$ & $(223 / 320)$ & $(208 / 326)$ & \\
\hline \multirow[t]{5}{*}{ BCS } & $\leq 2.5$ & 37.7 & 54.0 & 46.5 & 0.12 \\
\hline & $275-3.25$ & $\begin{array}{l}(26 / 69) \\
52.9\end{array}$ & $\begin{array}{l}(34 / 63) \\
67.7\end{array}$ & $\begin{array}{c}(33 / 71) \\
63.1\end{array}$ & \\
\hline & 2.100 .20 & $(199 / 376)$ & $(274 / 405)$ & $(238 / 377)$ & \\
\hline & $\geq 3.5$ & 52.4 & 58.3 & 74.1 & \\
\hline & & $(11 / 21)$ & $(7 / 12)$ & $(20 / 27)$ & \\
\hline \multirow[t]{4}{*}{ DIM at MSD } & $<60 \mathrm{~d}$ & $\begin{array}{l}36.9 \\
(60 / 187)\end{array}$ & $\begin{array}{c}56.0 \\
(107 / 101)\end{array}$ & $\begin{array}{l}52.3 \\
(101 / 103)\end{array}$ & 0.4 \\
\hline & $60-80 \mathrm{~d}$ & 60.7 & 70.6 & $\begin{array}{c}(101 / 190) \\
65.9\end{array}$ & \\
\hline & & $(127 / 209)$ & $(156 / 221)$ & $(141 / 214)$ & \\
\hline & $>80 \mathrm{~d}$ & 57.1 & 76.5 & 72.1 & \\
\hline
\end{tabular}

${ }^{1}$ Data are presented as raw means, and $P$-values are model adjusted.

${ }^{2}$ Control $=$ no treatment, bred at detected estrus (MSD); P4-Ov = a 7-d progesterone-releasing intravaginal device (PRID) with gonadotropin-releasing hormone $(\mathrm{GnRH})$ at PRID insertion and a luteolytic dose of $\mathrm{PGF}_{2 \alpha}$ at PRID removal; P4-Ov+eCG $=$ a 7-d PRID with GnRH at PRID insertion and a luteolytic dose of PGF ${ }_{2 \alpha}$ plus $500 \mathrm{IU}$ of equine chorionic gonadotropin (eCG) at PRID removal. Cows in treatments 2 and 3 received GnRH $56 \mathrm{~h}$ after PRID removal with timed AI performed $16 \mathrm{~h}$ later.

Use of eCG at the time of $\mathrm{P} 4$ device removal during a synchronization protocol has been associated with increased follicle size at ovulation and an associated larger CL and greater P4 output (reviewed by De Rensis and Lopez-Gatius, 2014). Progesterone is critical for the establishment and maintenance of pregnancy and plays a major role in regulating endometrial secretions essential for stimulating and mediating changes in conceptus growth and differentiation throughout early pregnancy in ruminants (Lonergan et al., 2016; Spencer et al., 2016). Numerous studies have demonstrated an association between elevated $\mathrm{P} 4$ and acceleration of conceptus elongation (Clemente et al., 2009; O'Hara et al., 2014, 2016; Randi et al., 2016). A variety of strategies can be used to increase peripheral $\mathrm{P} 4$ concentrations. These can be broadly classified as strategies that stimulate increased endogenous $\mathrm{P} 4$ production or strategies that rely on administration of exogenous $\mathrm{P} 4$ and include (1) manipulation of follicular development to increase the size of the preovulatory follicle and hence the size of the subsequent CL (Baruselli et al., 2012; Mesquita et al., 2014; Ramos et al., 2015); (2) direct stimulation of CL development with luteotropic agents (Maillo et al., 2014; Sánchez et al., 2018); (3) induction of accessory CL using appropriately timed administration of $\mathrm{GnRH}$ or human chorionic gonadotropin (Santos et al., 2001; Stevenson et al., 2007; De Rensis et al., 2010; Torres et al., 2013). Exogenous P4 supplementation has been achieved through injections (Garrett et al., 1988; Geisert et al., 1991; Pugliesi et al., 2014) or P4-containing devices (Stevenson et al., 2007; Carter et al., 2008; O'Hara et al., 2014, 2016).

The use of eCG in TAI programs for lactating dairy cows has led to inconsistent effects on pregnancy rate. 
Table 4. Effect of farm, parity, presence of a corpus luteum (CL), BCS, and DIM at mating start date (MSD) on 42 -d pregnancy rate (percentage of cows that successfully established pregnancy during the first $42 \mathrm{~d}$ of the breeding season) $)^{1,2}$

\begin{tabular}{|c|c|c|c|c|c|}
\hline \multirow[b]{2}{*}{ Variable } & \multirow[b]{2}{*}{ Category } & \multicolumn{3}{|c|}{ 42-d pregnancy rate, $\%$ (no./total) } & \multirow[b]{2}{*}{$P$-value } \\
\hline & & Control & $\mathrm{P} 4-\mathrm{Ov}$ & $\mathrm{P} 4-\mathrm{Ov}+\mathrm{eCG}$ & \\
\hline \multirow[t]{5}{*}{ Farm } & 1 & $\begin{array}{l}80.0 \\
(96 / 120)\end{array}$ & $\begin{array}{c}84.1 \\
(106 / 126)\end{array}$ & $\begin{array}{l}84.5 \\
(98 / 116)\end{array}$ & \multirow[t]{5}{*}{$<0.0001$} \\
\hline & 2 & $\begin{array}{l}74.6 \\
(41 / 55)\end{array}$ & $\begin{array}{c}79.6 \\
(43 / 54)\end{array}$ & $\begin{array}{l}75.9 \\
(41 / 54)\end{array}$ & \\
\hline & 3 & 50.0 & 63.8 & 57.1 & \\
\hline & & $(49 / 98)$ & $(67 / 105)$ & $(64 / 112)$ & \\
\hline & 4 & $\begin{array}{c}75.7 \\
(146 / 193)\end{array}$ & $\begin{array}{c}83.6 \\
(163 / 195)\end{array}$ & $\begin{array}{c}77.7 \\
(150 / 193)\end{array}$ & \\
\hline \multirow[t]{4}{*}{ Parity } & 1 & $\begin{array}{l}70.9 \\
(83 / 112)\end{array}$ & $\begin{array}{l}76.4 \\
(94 / 123)\end{array}$ & $\begin{array}{l}79.0 \\
(94 / 119)\end{array}$ & \multirow[t]{4}{*}{0.9} \\
\hline & 2 & $\begin{array}{l}73.9 \\
(85 / 115)\end{array}$ & $\begin{array}{l}83.6 \\
(97 / 116)\end{array}$ & $\begin{array}{l}71.8 \\
(84 / 117)\end{array}$ & \\
\hline & $\geq 3$ & 70.1 & 78.0 & 73.2 & \\
\hline & & $(164 / 234)$ & $(188 / 241)$ & $(175 / 239)$ & \\
\hline \multirow[t]{3}{*}{ CL status } & Absent & $\begin{array}{c}71.0 \\
(103 / 145)\end{array}$ & $\begin{array}{c}75.0 \\
(117 / 156)\end{array}$ & $\begin{array}{c}71.9 \\
(105 / 146)\end{array}$ & \multirow[t]{3}{*}{0.9} \\
\hline & Present & 71.5 & 80.9 & 75.5 & \\
\hline & & $(226 / 316)$ & $(259 / 320)$ & $(246 / 326)$ & \\
\hline \multirow[t]{4}{*}{ BCS } & $\leq 2.5$ & $\begin{array}{l}72.5 \\
(50 / 69)\end{array}$ & $\begin{array}{l}71.4 \\
(45 / 63)\end{array}$ & $\begin{array}{l}62.0 \\
(44 / 71)\end{array}$ & \multirow[t]{4}{*}{0.24} \\
\hline & $2.75-3.25$ & 70.7 & 80.3 & 75.9 & \\
\hline & & $(266 / 376)$ & $(325 / 405)$ & $(286 / 377)$ & \\
\hline & $\geq 3.5$ & $\begin{array}{l}76.2 \\
(16 / 21)\end{array}$ & $\begin{array}{l}75.0 \\
(9 / 12)\end{array}$ & $\begin{array}{l}85.2 \\
(23 / 27)\end{array}$ & \\
\hline \multirow[t]{5}{*}{ DIM at MSD } & $<60 \mathrm{~d}$ & 63.1 & 71.2 & 69.4 & \multirow[t]{5}{*}{0.4} \\
\hline & & (118/187) & $(136 / 191)$ & (134/193) & \\
\hline & $60-80 \mathrm{~d}$ & $\begin{array}{c}76.6 \\
(160 / 209)\end{array}$ & $\begin{array}{c}82.8 \\
(183 / 221)\end{array}$ & $\begin{array}{c}75.7 \\
(162 / 214)\end{array}$ & \\
\hline & $>80 \mathrm{~d}$ & 77.1 & 88.2 & 83.8 & \\
\hline & & $(54 / 70)$ & $(60 / 68)$ & $(57 / 68)$ & \\
\hline
\end{tabular}

${ }^{1}$ Data are presented as raw means, and $P$-values are model adjusted.

${ }^{2}$ Control $=$ no treatment, bred at detected estrus (MSD); P4-Ov $=$ a 7 -d progesterone-releasing intravaginal device (PRID) with gonadotropin-releasing hormone $(\mathrm{GnRH})$ at PRID insertion and a luteolytic dose of $\mathrm{PGF}_{2 \alpha}$ at PRID removal; P4-Ov+eCG $=$ a 7-d PRID with GnRH at PRID insertion and a luteolytic dose of PGF ${ }_{2 \alpha}$ plus $500 \mathrm{IU}$ of equine chorionic gonadotropin (eCG) at PRID removal. Cows in treatments 2 and 3 received GnRH $56 \mathrm{~h}$ after PRID removal with timed AI performed $16 \mathrm{~h}$ later.

Souza et al. (2009) found no overall increase in pregnancy per AI after administration of $400 \mathrm{IU}$ of eCG at the end of an 8-d P4-based program. An increase in post-AI P4 concentrations was reported, however, suggesting that subsequent CL function was altered after eCG potentially affected ovulatory follicle growth (Souza et al., 2009; De Rensis and Lopez-Gatius, 2014). Although overall pregnancy rate was not affected, eCG had a positive effect on pregnancy rate when only thin cows were considered (Souza et al., 2009). Similar results were obtained in a subsequent trial where the administration of $600 \mathrm{IU}$ of eCG failed to improve P/AI compared with a control group (Ferreira et al., 2013). In a further study, eCG addition failed to increase pregnancy rates in cows receiving a Presynch-Ovsynch protocol (Pulley et al., 2013). Interestingly, 2 studies conducted under pasture-based systems in New Zealand (Bryan et al.,
2013; Shephard, 2013) reported a significant increase in pregnancy rate/AI in anestrous lactating dairy cows treated with a P4-Ovsynch program supplemented with eCG. Both studies demonstrated that eCG had a beneficial effect on earlier calved cows that were still anestrous at the initiation of the breeding season. A significantly higher proportion of cows were pregnant in the first $28 \mathrm{~d}$ post-TAI in the eCG-supplemented group compared with the other synchronization treatments used. These observations are in agreement with other studies that have investigated the effect of eCG on reproductive performance of anestrous beef cows (reviewed in Bó and Baruselli, 2014; Bó et al., 2016). A recent report analyzed the effect of eCG treatment at the end of a $\mathrm{P} 4$-based synchronization program on fertility performances of crossbred (Bos taurus $\times$ Bos indicus) dairy cows in a pasture-based system. Treat- 
ment with eCG increased the risk of conception for cows that were in the early postpartum period $(\leq 70$ DIM; Prata et al., 2017). The lack of an effect of eCG in the present study, even in cows with low BCS, may be due to the numbers of cows in the 3 BCS categories being highly unbalanced, with most cows having a BCS of 2.75 to 3.25 .

The proportion of anovular cows at the end of the voluntary waiting period has been reported to vary from 5 to $40 \%$ across dairy herds (reviewed by Santos et al., 2016). However, anestrous cows are infrequent where an adequate plane of nutrition is in place (Crowe et al., 2014); in the current study, $31 \%(447 / 1,421)$ of all cows enrolled lacked a CL at ultrasonography at d -10 . Lack of a CL at a single scan is likely to lead to an overestimation of acyclicity; nonetheless, there was no effect of CL presence on final pregnancy rate or on the interval from MSD to conception.

The effect of eCG treatment was tested on lactating dairy cows managed under a mixed pasture-TMR system in Argentina. No effects of eCG on follicular diameter at TAI or post-AI P4 concentration were reported and, consistent with the results of the current study, no difference was found in pregnancy rates between eCGsupplemented cows and control cows (Bó et al., 2013).

The likelihood of pregnancy establishment following an AI at detected estrus or after either of the TAI protocols was not different in the current study. The favorable effects of the TAI protocols on the fertility metrics observed in the study is a consequence of greater $(100 \%)$ and earlier (MSD) submission rate of eligible cows compared with control cows, which show heat at varying times after the start of the breeding season.

Economic losses due to poor fertility are normally attributable to the cost of a prolonged calving interval, increased insemination costs, reduced returns from calves born, and an increased replacement rate arising from greater involuntary culling due to fertility failure (Van Arendonk et al., 1989; Esslemont et al., 2001). The cost of each 1-d increase in calving interval for an Irish dairy producer, calculated as slippage from the optimum herd mean calving day of mid-February, has been estimated at €3.86/cow (Shalloo et al., 2014). Moreover, the calving interval is highly correlated with days to first service (0.93), whereas the first service to conception interval is only moderately correlated with the calving interval ( -0.56 ; Pryce et al., 1997, 1998). Thus, a systematic approach of synchronization at the initiation of the breeding season can facilitate a significant reduction in calving interval, allowing better utilization of the pasture resource and a consequent increase in milk production over the following calving/ breeding season. This is particularly relevant to herds that have either a later than optimum mean calving date or a high proportion of anestrous cows at the start of the breeding period.

In conclusion, use of a TAI program at the initiation of the breeding season in a pasture-based system accelerated the rate of pregnancy establishment, with a mean reduction of $10 \mathrm{~d}$ open, resulting in extra days in milk for the cows in the synchronized treatments. These data confirm that TAI programs can play an important role as a management tool for seasonal breeding systems. Under the conditions of the current study, eCG treatment during P4-Ovsynch failed to improve reproduction outcomes in seasonal-calving dairy cows.

\section{ACKNOWLEDGMENTS}

The authors thank the owners and farm staff at the 4 farms enrolled in this study for their invaluable collaboration. Also, authors thank Ceva Santé Animale for supplying the drugs used for the synchronization protocol. This work was funded by the Department of Agriculture, Food and the Marine (Dublin, Ireland; Research Stimulus Fund, Grants 13S515 and13S528).

\section{REFERENCES}

Baruselli, P. S., M. F. Sa Filho, R. M. Ferreira, J. N. Sales, L. U. Gimenes, L. M. Vieira, M. F. Mendanha, and G. A. Bo. 2012. Manipulation of follicle development to ensure optimal oocyte quality and conception rates in cattle. Reprod. Domest. Anim. 47(Suppl. 4):134-141. https://doi.org/10.1111/j.1439-0531.2012.02067.x.

Bisinotto, R. S., I. J. Lean, W. W. Thatcher, and J. E. Santos. 2015. Meta-analysis of progesterone supplementation during timed artificial insemination programs in dairy cows. J. Dairy Sci. 98:24722487. https://doi.org/10.3168/jds.2014-8954.

Bó, G., P. Baruselli, and R. Mapletoft. 2013. Synchronization techniques to increase the utilization of artificial insemination in beef and dairy cattle. Anim. Reprod. 10:137-142.

Bó, G. A., and P. S. Baruselli. 2014. Synchronization of ovulation and fixed-time artificial insemination in beef cattle. Animal 8(Suppl. 1):144-150. https://doi.org/10.1017/S1751731114000822.

Bó, G. A., J. J. de la Mata, P. S. Baruselli, and A. Menchaca. 2016. Alternative programs for synchronizing and resynchronizing ovulation in beef cattle. Theriogenology 86:388-396. https://doi.org/10 $.1016 /$ j.theriogenology.2016.04.053.

Bryan, M. A., G. Bo, R. J. Mapletoft, and F. R. Emslie. 2013. The use of equine chorionic gonadotropin in the treatment of anestrous dairy cows in gonadotropin-releasing hormone/progesterone protocols of 6 or 7 days. J. Dairy Sci. 96:122-131. https://doi.org/10 .3168/jds.2012-5452.

Bryan, M. A., G. A. Bo, C. Heuer, and F. R. Emslie. 2010. Use of equine chorionic gonadotrophin in synchronised AI of seasonalbreeding, pasture-based, anoestrous dairy cattle. Reprod. Fertil. Dev. 22:126-131. https://doi.org/10.1071/RD09225.

Caraviello, D. Z., K. A. Weigel, P. M. Fricke, M. C. Wiltbank, M. J. Florent, N. B. Cook, K. V. Nordlund, N. R. Zwald, and C. L. Rawson. 2006. Survey of management practices on reproductive performance of dairy cattle on large US commercial farms. J. Dairy Sci. 89:4723-4735. https://doi.org/10.3168/jds.S0022 -0302(06)72522-X.

Carter, F., N. Forde, P. Duffy, M. Wade, T. Fair, M. A. Crowe, A. C. Evans, D. A. Kenny, J. F. Roche, and P. Lonergan. 2008. Effect 
of increasing progesterone concentration from Day 3 of pregnancy on subsequent embryo survival and development in beef heifers. Reprod. Fertil. Dev. 20:368-375.

Clemente, M., J. de La Fuente, T. Fair, A. Al Naib, A. GutierrezAdan, J. F. Roche, D. Rizos, and P. Lonergan. 2009. Progesterone and conceptus elongation in cattle: A direct effect on the embryo or an indirect effect via the endometrium? Reproduction 138:507517. https://doi.org/10.1530/REP-09-0152.

Crowe, M. A., M. G. Diskin, and E. J. Williams. 2014. Parturition to resumption of ovarian cyclicity: comparative aspects of beef and dairy cows. Animal 8(Suppl. 1):40-53. https://doi.org/10.1017/ S1751731114000251.

De Rensis, F., and F. Lopez-Gatius. 2014. Use of equine chorionic gonadotropin to control reproduction of the dairy cow: A review. Reprod. Domest. Anim. 49:177-182. https://doi.org/10.1111/rda .12268 .

De Rensis, F., F. Lopez-Gatius, I. Garcia-Ispierto, and M. Techakumpu. 2010. Clinical use of human chorionic gonadotropin in dairy cows: An update. Theriogenology 73:1001-1008. https://doi.org/ 10.1016/j.theriogenology.2009.11.027

Dillon, P., S. Crosse, G. Stakelum, and F. Flynn. 1995. The effect of calving date and stocking rate on the performance of springcalving dairy cows. Grass Forage Sci. 50:286-299.

Edmonson, A., I. Lean, L. Weaver, T. Farver, and G. Webster. 1989. A body condition scoring chart for Holstein dairy cows. J. Dairy Sci. 72:68-78.

Esslemont, R., M. Kossaibati, and J. Allcock,. 2001. Economics of fertility in dairy cows. BSAS Occasional Publication 19-30. Br. Soc. Anim. Sci., Penicuik, UK.

Ferreira, R. M., H. Ayres, J. N. Sales, A. H. Souza, C. A. Rodrigues, and P. S. Baruselli. 2013. Effect of different doses of equine chorionic gonadotropin on follicular and luteal dynamics and $\mathrm{P} / \mathrm{AI}$ of high-producing Holstein cows. Anim. Reprod. Sci. 140:26-33. https://doi.org/10.1016/j.anireprosci.2013.04.014.

Garrett, J. E., R. D. Geisert, M. T. Zavy, L. K. Gries, R. P. Wettemann, and D. S. Buchanan. 1988. Effect of exogenous progesterone on prostaglandin F2 alpha release and the interestrous interval in the bovine. Prostaglandins 36:85-96.

Geisert, R. D., T. C. Fox, G. L. Morgan, M. E. Wells, R. P. Wettemann, and M. T. Zavy. 1991. Survival of bovine embryos transferred to progesterone-treated asynchronous recipients. J. Reprod. Fertil. 92:475-482.

Herlihy, M. M., D. P. Berry, M. A. Crowe, M. G. Diskin, and S. T. Butler. 2011. Evaluation of protocols to synchronize estrus and ovulation in seasonal calving pasture-based dairy production systems. J. Dairy Sci. 94:4488-4501. https://doi.org/10.3168/jds .2010-4126.

Herlihy, M. M., M. A. Crowe, D. P. Berry, M. G. Diskin, and S. T. Butler. 2013. Factors associated with fertility outcomes in cows treated with protocols to synchronize estrus and ovulation in seasonal-calving, pasture-based dairy production systems. J. Dairy Sci. 96:1485-1498. https://doi.org/10.3168/jds.2011-5250.

Keith, B. R., K. E. Leslie, W. H. Johnson, and J. S. Walton. 2005. Effect of presynchronization using prostaglandin F2 $\alpha$ and a milkejection test on pregnancy rate after the timed artificial insemination protocol, Ovsynch. Theriogenology 63:722-738. https://doi .org/10.1016/j.theriogenology.2004.03.023.

Lonergan, P., N. Forde, and T. Spencer. 2016. Role of progesterone in embryo development in cattle. Reprod. Fertil. Dev. 28:66-74 https://doi.org/10.1071/RD15326.

Maillo, V., P. Duffy, L. O'Hara, C. de Frutos, A. K. Kelly, P. Lonergan, and D. Rizos. 2014. Effect of hCG administration during corpus luteum establishment on subsequent corpus luteum development and circulating progesterone concentrations in beef heifers. Reprod. Fertil. Dev. 26:367-374. https://doi.org/10.1071/RD12353.

McDougall, S. 2010. Effects of treatment of anestrous dairy cows with gonadotropin-releasing hormone, prostaglandin, and progesterone. J. Dairy Sci. 93:1944-1959. https://doi.org/10.3168/jds.2009-2305.

Mesquita, F. S., G. Pugliesi, S. C. Scolari, M. R. Franca, R. S. Ramos, M. Oliveira, P. C. Papa, F. F. Bressan, F. V. Meirelles, L. A. Silva,
G. P. Nogueira, C. M. Membrive, and M. Binelli. 2014. Manipulation of the periovulatory sex steroidal milieu affects endometrial but not luteal gene expression in early diestrus Nelore cows. Theriogenology 81:861-869. https://doi.org/10.1016/j.theriogenology .2013.12.022.

O'Hara, L., N. Forde, F. Carter, D. Rizos, V. Maillo, A. D. Ealy, A. K. Kelly, P. Rodriguez, N. Isaka, A. C. Evans, and P. Lonergan. 2014. Paradoxical effect of supplementary progesterone between Day 3 and Day 7 on corpus luteum function and conceptus development in cattle. Reprod. Fertil. Dev. 26:328-336. https://doi.org/ 10.1071/RD12370.

O'Hara, L., N. Forde, P. Duffy, F. Randi, A. K. Kelly, A. Valenza, P. Rodriguez, and P. Lonergan. 2016. Effect of combined exogenous progesterone with luteotrophic support via equine chorionic gonadotrophin (eCG) on corpus luteum development, circulating progesterone concentrations and embryo development in cattle. Reprod. Fertil. Dev. 28:269-277. https://doi.org/10.1071/RD14019.

Prata, A. B., G. C. S. Pontes, P. L. J. Monteiro, J. N. Drum, M. C. Wiltbank, and R. Sartori. 2017. Equine chorionic gonadotropin increases fertility of grazing dairy cows that receive fixedtime artificial insemination in the early but not later postpartum period. Theriogenology 98:36-40. https://doi.org/10.1016/j .theriogenology.2017.04.041.

Pryce, J. E., R. J. Esslemont, R. Thompson, R. F. Veerkamp, M. A. Kossaibati, and G. Simm. 1998. Estimation of genetic parameters using health, fertility and production data from a management recording system for dairy cattle. Anim. Sci. 66:577-584.

Pryce, J. E., R. F. Veerkamp, R. Thompson, W. G. Hill, and G. Simm. 1997. Genetic aspects of common health disorders and measures of fertility in Holstein Friesian dairy cattle. Anim. Sci. 65:353-360.

Pugliesi, G., M. L. Oliveria, S. C. Scolari, E. Lopes, F. V. Pinaffi, B. T Miagawa, Y. N. Paiva, J. R. Maio, G. P. Nogueira, and M Binelli.. 2014. Corpus luteum development and function after supplementation of long-acting progesterone during the early luteal phase in beef cattle. Reprod. Domest. Anim. 49:85-91. https://doi.org/10 $.1111 /$ rda. 12231.

Pulley, S. L., L. D. Wallace, H. I. Mellieon, Jr. and J. S. Stevenson. 2013. Ovarian characteristics, serum concentrations of progesterone and estradiol, and fertility in lactating dairy cows in response to equine chorionic gonadotropin. Theriogenology 79:127-134. https://doi.org/10.1016/j.theriogenology.2012.09.017.

Pursley, J. R., M. O. Mee, and M. C. Wiltbank. 1995. Synchronization of ovulation in dairy cows using PGF2alpha and GnRH. Theriogenology 44:915-923.

Ramos, R. S., M. L. Oliveira, A. P. Izaguirry, L. M. Vargas, M. B. Soares, F. S. Mesquita, F. W. Santos, and M. Binelli. 2015. The periovulatory endocrine milieu affects the uterine redox environment in beef cows. Reprod. Biol. Endocrinol. 13:39. https://doi .org/10.1186/s12958-015-0036-x.

Randi, F., B. Fernandez-Fuertes, M. McDonald, N. Forde, A. K. Kelly, H. Bastos Amorin, E. Muniz de Lima, F. Morotti, M. Marcondes Seneda, and P. Lonergan. 2016. Asynchronous embryo transfer as a tool to understand embryo-uterine interaction in cattle: Is a large conceptus a good thing? Reprod. Fertil. Dev. 28:1999-2006. https: //doi.org/10.1071/RD15195.

Rhodes, F. M., S. McDougall, C. R. Burke, G. A. Verkerk, and K. L. Macmillan. 2003. Invited review: Treatment of cows with an extended postpartum anestrous interval. J. Dairy Sci. 86:1876-1894 https://doi.org/10.3168/jds.S0022-0302(03)73775-8.

Sánchez, J. M., F. Randi, C. Passaro, D. J. Mathew, S. T. Butler, and P. Lonergan. 2018. Effect of human chorionic gonadotrophin administration 2 days after insemination on progesterone concentration and pregnancy per artificial insemination in lactating dairy cows. J. Dairy Sci. https://doi.org/10.3168/jds.2017-14058.

Santos, J. E., R. Bisinotto, and E. Ribeiro. 2016. Mechanisms underlying reduced fertility in anovular dairy cows. Theriogenology 86:254-262. https://doi.org/10.1016/j.theriogenology.2016.04.038.

Santos, J. E., W. W. Thatcher, L. Pool, and M. W. Overton. 2001 Effect of human chorionic gonadotropin on luteal function and re- 
productive performance of high-producing lactating Holstein dairy cows. J. Anim. Sci. 79:2881-2894.

Shalloo, L., A. Cromie, and N. McHugh. 2014. Effect of fertility on the economics of pasture-based dairy systems. Animal 8(Suppl. 1):222-231. https://doi.org/10.1017/S1751731114000615.

Shephard, R. W. 2013. Efficacy of inclusion of equine chorionic gonadotrophin into a treatment protocol for anoestrous dairy cows. N. Z. Vet. J. 61:330-336.

Souza, A. H., S. Viechnieski, F. A. Lima, F. F. Silva, R. Araujo, G. A. Bo, M. C. Wiltbank, and P. S. Baruselli. 2009. Effects of equine chorionic gonadotropin and type of ovulatory stimulus in a timedAI protocol on reproductive responses in dairy cows. Theriogenology 72:10-21. https://doi.org/10.1016/j.theriogenology.2008.12 .025 .

Spencer, T. E., N. Forde, and P. Lonergan. 2016. The role of progesterone and conceptus-derived factors in uterine biology during early pregnancy in ruminants. J. Dairy Sci. 99:5941-5950. https://doi .org/10.3168/jds.2015-10070.
Stevenson, J. S., M. A. Portaluppi, D. E. Tenhouse, A. Lloyd, D. R. Eborn, S. Kacuba, and J. M. DeJarnette. 2007. Interventions after artificial insemination: Conception rates, pregnancy survival, and ovarian responses to gonadotropin-releasing hormone, human chorionic gonadotropin, and progesterone. J. Dairy Sci. 90:331-340. https://doi.org/10.3168/jds.S0022-0302(07)72634-6.

Torres, A., J. Chagas e Silva, M. C. Deloche, P. Humblot, A. E. Horta, and L. Lopes-da-Costa. 2013. Secondary corpora lutea induced by HCG treatment enhanced demi-embryo survival in lactating highyielding dairy cows. Reprod. Domest. Anim. 48:643-650. https:// doi.org/10.1111/rda.12138.

Van Arendonk, J. A., R. Hovenier, and W. De Boer. 1989. Phenotypic and genetic association between fertility and production in dairy cows. Livest. Prod. Sci. 21:1-12.

Wiltbank, M. C., and J. R. Pursley. 2014. The cow as an induced ovulator: timed AI after synchronization of ovulation. Theriogenology 81:170-185. https://doi.org/10.1016/j.theriogenology.2013.09.017. 